\title{
Pengembangan Media Kartu Kamal dalam Penguasaan Kosakata Bahasa Arab
}

\author{
M. Syamsul Ma'arif \\ Institut Agama Islam Negeri Kediri \\ msymaari@gmail.com
}

\begin{abstract}
Vocabulary is one element of language that must be mastered by learners in mastering a particular language including Arabic. Learning Arabic vocabulary requires its own strategies so that the learning will not be boring, one of them is a card games. This study aims to develop Arabic vocabulary learning media in the form of cards named "kamal" as well as to determine their effectiveness. The research design uses Research and Devolopment ( $R$ D) method. Based on the results of the study, it was shown that the kamal card was effectively used as an alternative to the Arabic vocabulary learning media seen from the differences in Student's pre-test and post-test scores. The results of the $t$-test are obtained $t \wedge($ count $)>t \wedge$ table. In the Class " $B$ " series 1 and series $2 t \wedge$ (count) it is 5.390 and 6.890, while the class " $D$ " series 1 and series $2 t \wedge$ (count) are 9.335 and 9.054 with coefficients $(d k=6)$ then $t \wedge$ table between the two classes are the same $(2,466)$.
\end{abstract}

Keywords: kamal card, game media, mufrodat.

\begin{abstract}
Abstrak
Kosakata merupakan salah satu unsur bahasa penting dalam pembelajaran bahasa Arab. Pembelajaran kosakata bahasa Arab (murodat) membutuhkan strategi tersendiri agar tidak menjenuhkan, salah satunya adalah dengan media pembelajaran. Penelitian ini dilakukan untuk mengembangkan media permainan kartu untuk pembelajaran mufrodat serta mengetahui pengaruhnya terhadap hasil belajar peserta didik. Rancangan penelitian ini menggunakan metode Research and Devolopment (RED) yang diujicobakan pada Mahasiswa IAIN Kediri semester pertama. Hasil penelitian menunjukkan bahwa 1) media kartu kamal untuk penguasaan kosa kata bahasa Arab dengan kriteria "Sangat Baik", penilaian ahli media dengan presentase $96 \%$ penilaian ahli isi $92 \%$ dan penilaian ahli pembelajaran 93\%. 2) media kartu kamal terbukti efektif dilihat dari perbedaan dari nilai pre-test dan post test. Adapun dari hasil uji $t$ diperoleh $t^{\text {hitung }}>t^{\text {tabel }} u$ ntuk kelas LAM "B" pada kartu $1 t^{\text {hitung }}$ nya adalah 5,390 dan pada kartu $2 t^{\text {hitung }}$ nya adalah 6,890 dengan koefisisen (dk=6) maka $t^{\text {tabel }}$ nya adalah 2,466. Sedangkan untuk kelas LAM “D” pada kartu 1 $t^{\text {hitung }}$ nya adalah 9,353 dan pada kartu $2 t^{\text {hitung }}$ nya adalah 9,054 dengan koefisisen $(\mathrm{dk}=6)$ maka $t^{\text {tabel }}$ nya juga sama yaitu 2,466. Berdasarkan hasil analisis, media kartu permainan kamal mendapatkan respon positif dari mahasiswa dan layak dijadikan salah satu media pembelajaran bahasa Arab, khususnya dalam pembelajaran mufrodat.
\end{abstract}


Kata kunci: media pembelajaran; permainan kartu kamal; mufrodat.

\section{A. Pendahuluan}

Salah satu bahasa Internasional yang yang diakui oleh PBB adalah bahasa Arab. Bahasa Arab merupakan bahasa resmi untuk beberapa negara yang berada pada kawasan Asia Barat dan Afrika Utara. Bahasa Arab juga menjadi bahasa pendidikan, ilmu pengetahuan, diplomasi, transaksi sosial dan ekonomi, dan budaya. ${ }^{1}$ Terdapat juga berbagai literatur terkait dengan ilmu pengetahuan, pendidikan, bisnis, hiburan dan lainnya yang ditulis dengan bahasa Arab. Pengajaran bahasa Arab di Indonesia bermula bersamaan dengan masuknya Islam ke Indonesia. Sehingga bahasa Arab menjadi satu-satunya bahasa yang memiliki derajat tinggi di kalangan muslim karena bahasa Arab menjadi bahasa pengantar bagi sumber agama Islam.

Bahasa Arab di Indonesia menjadi salah satu mata pelajaran wajib pada satuan pendidikan dibawah naungan Kemenag, mulai dari tingkatan dasar hingga perguruan tinggi. Seluruh satuan pendidikan tersebut mengajar bahasa Arab sebagai salah satu bahasa Asing yang diajarkan selain bahasa Inggris. Akan tetapi pelaksanaan atau penerapannya dalam pembelajaran mengalami berabagi macam masalah, salah satu masalah yang dihadapi adalah rasa kebosanan para pembelajar dalam belajar bahasa serta kurangnya penguasaan dan juga inovasi pengajar dalam proses pembelajaran dikelas. Baik terkait dengan materi, strategi, metode, teknik, evaluasi ataupun media pembelajarannya.

Salah satu solusi untuk mengatasi permasalahan dalam pembelajaran adalah dengan pemanfaatan media pembelajaran. Media pembelajaran merupakan sebuah alat bantu komunikasi antara guru dan siswa untuk mempermudah penyampaian suatu informasi dalam sebuah pembelajaran. Akan tetapi yang terpenting bukanlah medianya saja melainkan pesan pembelajaran yang dibawakan oleh media tersebut. ${ }^{2}$ Adanya media pembelajaran diharapkan dapat meningkatkan motivasi dan minat siswa dalam belajar, membantu meningkatkan pemahaman, menyajikan data dengan cara yang lebih menarik dan memahamkan, serta menambah semangat untuk belajar. Penggunaan media pembelajaran secara tepat dapat membantu dalam mencapai pembelajaran yang efektif dan efisien. Disamping bentuk dari media pembelajaran yang tepat guna, dalam sebuah proses pembelajaran juga dibutuhkan keterampilan guru dalam memanfaatkan media tersebut sehingga tujuan pembelajaran dapat tercapai dengan baik.

Adapun dalam sebuah bahasa terdapat dua hal yang harus dipelajari, yaitu unsur bahasa dan keterampilan berbahasa. Unsur bahasa meliputi suara, kosakata dan tata bahasa. Sedangkan keterampilan bahasa meliputi keterampilan mendengar, berbicara, membaca dan menulis. Unsur dan

${ }^{1}$ Azhar Arsyad, hlm.1.

2 Dina Indriana, Ragam Alat Bantu Media Pengajaran (Yogyakarta: Diva Press, 2011), hlm.21. 
keterampilan bahasa ini bersifat universal, dan berlaku bagi seluruh pembelajaran bahasa Asing termasuk bahasa Arab. Kedua hal tersebut hendaknya diajarkan kepada para pembelajar dengan cara yang baik, tepat dan menyenangkan agar tujuan pembelajaran yang direncakan dapat terwujud. Salah satu caranya adalah dengan adanya kreatifitas pengajar secara terus menerus dalam mengembangkan media pembelajaran yang digunakan.

Salah satu unsur bahasa asing yang sangat penting untuk dikuasai oleh pembelajar adalah kosakata. Penguasaan kosakata Arab (mufrodat) menjadi salah satu kunci dalam penguasaan bahasa Arab. Kelemahan pembelajar dalam penguasaan bahasa Arab salah satunya adalah karena minimnya kosakata yang dimiliki sehingga pembelajar merasa bahwa belajar bahasa sangatlah sulit dan membosankan. Padahal penguasaaan mufrodat berperan penting dalam empat keterampilan berbahasa. Menurut Vallet bahwa kemampuan seseorang untuk memahami empat kemahiran berbahasa tergantung pada penguasaan kosakata yang dimiliki. ${ }^{3}$

Permasalahan minimnya perbendaharaan kosakata ini tidak hanya dirasakan oleh pembelajar pemula, tetapi juga dihadapi oleh pembelajar bahasa pada tingkatan Mahasiswa yang notabenenya sudah belajar bahasa Arab sebelumnya. Sebagaimana yang dialami oleh Mahasiswa IAIN Kediri semester pertama. Mereka merasa kesulitan dalam menambah perbendaharaan mufrodat karena mengahafal mufrodat adalah suatu kegiatan yang sangat membosankan dan melelahkan. Berdasarkan pada permasalahan yang terjadi secara luas tersebut dan juga kebutuhan akan adanya sebuah cara alternatif untuk mengatasi permasalahan tersebut, peneliti untuk mengembangkan sebuah media pembelajaran inovatif berupa permainan kartu yang diharapkan mampu menjadi solusi bagi permasalahan penguasaan mufrodat.

Kartu merupakan salah satu media visual yang tidak diproyeksikan. Adapun berdasarkan jenis perkembangannya kartu termasuk media hasil teknologi cetak. ${ }^{4}$ Sedangkan permainan adalah suatu kegiatan yang berisi peraturan tertentu untuk tujuan refreshing dan kesenangan. Jadi media kartu permainan merupakan sebuah kartu yang berisi informasi yang dapat dimainkan dengan mengikuti beberapa aturan tertentu dengan tujuan belajar dan bersenang-senang. Kartu juga sering kita manfaatkan untuk memberi penguatan pada siswa (drilling) mengenai suatu konsep bahasa tertentu ataupun untuk memberi kesempatan siswa dalam mempraktikkan aspek bahasa yang sudah dipelajari atau dikenal. ${ }^{5}$

Adapun kartu kamal merupakan sebuah kartu yang dikembangkan untuk pembelajaran bahasa Arab khususnya untuk penguasaan mufrodat dengan cara yang menyenangkan. Kartu ini berisi puluhan mufrodat secara

${ }^{3}$ Syaiful Mustofa, Strategi Pembelajaraan Bahasa Arab Inovatif (Malang: UIN Maliki Press, 2011), hlm.61.

${ }^{4}$ Cecep Kustandi, Bambang Sutjipto, Media Pembelajaran Manual Dan Digital (Bogor: Ghalia Indonesia, 2013), hlm.29-31.

${ }^{5}$ Abdul Wahab Rosyidi, Media Pembelajaran Bahasa Arab (Malang: UIN Malang Press, 2009), hlm.20-21. 
tematik baik berupa kata benda maupun kata kerja. Permainan ini merupakan sebuah pengembangan dari permainan kartu Uno. Pengembangan media berupa kartu permianan ini diharapkan dapat menjadi salah satu solusi bagi seluruh pembelajar bahasa Arab dalam menguasai mufrodat. Sebagaimana pemaparan diatas, Peneliti mengangkat permasalahan tersebut dalam sebuah Penelitian pengembangan $(R n D)$ yang berjudul "Pengembangan Kartu Kamal dalam Meningkatkan Penguasaan Kosakata Bahasa Arab.

\section{B. PEMBAHASAN}

\section{A. KAJIAN TEORI}

1. Media Pembelajaran

Media menurut bahasa diartikan sebagai alat, sarana komunikasi, perantara atau penghubung. ${ }^{6}$ Kata media berasal dari bahasa Latin dan merupakan bentuk jamak dari kata medium yang berarti perantara atau pengantar. ${ }^{7}$ Dalam bahasa Arab media disebut dengan wasilah untuk bentuk tunggal dan wasail untuk bentuk plural (jamak).

Gerlach dan Ely mengatakan bahwa media secara garis besar adalah manusia, materi atau kejadian yang membangun kondisi yang membuat siswa mampu memperoleh pengetahuan, keterampilan atau sikap. Hannick dkk juga mendefinisikan media sebagai perantara yang mengantarkan informasi antara sumber dan penerima. ${ }^{8}$ Amir Achsin juga mengartikan media sebagai setiap orang, bahan, alat atau kejadian yang memantapkan kondisi yang memungkinkan siswa memperoleh pengetahuan, keterampilan dan sikap. Dalam pengertian luas, segala hal yang menjadi perantara antara pesan dan penerima pesan seperti guru, buku teks, lingkungan sekolah dan lainnya juga disebut sebagai media. ${ }^{9}$

\section{Permainan Kartu Kamal}

Kartu kamal ini merupakan sebuah pengembangan dari sebuah media permainan kartu UNO. Kartu Uno adalah sebuah kartu yang dikembangkan oleh Marie Robbins pada tahun 1971. Permainan ini hampir mirip dengan permainan remi. Cara bermain Uno adalah dengan mencocokkan angka atau warna kartu pemain dengan kartu tarikan. Media kartu yang dikembangkan untuk penelitian ini adalah kartu yang didesain khusus untuk pembelajaran bahasa Arab.

\section{B. METODOLOGI PENELITIAN}

Metode penelitian yang digunakan dalam penelitian ini adalah metode penelitian dan pengembangan (research and development). Penelitian $R \& D$

\footnotetext{
${ }^{6}$ KBBI, aplikasi KBBI Offline Versi 1.1

7 Arief S. Sadiman dkk, Media Pendidikan: Pengertian, Pengembangan, dan Pemanfaatan, (Surabaya: Insan Cendikia) 2011, hlm. 6

8 Azhar Arsyad, Bahasa Arab dan Metode Pengajarannya (Yogyakarta: Pustaka Pelajar, 2003), hlm. 3-4.

${ }_{9}^{9}$ Amir Achsin, Media Pendidikan (Ujung Pandang: IKIP, 1986), hlm. 9.
} 
merupakan sebuah penelitian dan pengembangan yang bersifat longitudinal atau bertahap. Penelitian ini berusaha untuk menghasilkan suatu produk tertentu yang berlandaskan pada analisis kebutuhan dan pengujian keefektifan produk supaya dapat bermanfaat pada masyarakat luas. ${ }^{10}$ Sedangkan Menurut Borg and Gall, yang dimaksud dengan model penelitian dan pengembangan $(R$ $\mathcal{E} D$ ) adalah :a process used develop and validate educational product". ${ }^{11}$ Penelitian ini menggunakan model pengembangan research and development (RED) Borg and Gall yang telah dimodifikasi oleh Sugiyono yang terdiri dari sepuluh langkah diantaranya analisis potensi dan masalah, pengumpulan data, desain produk, validasi desain, revisi desain, uji coba produk, revisi produk, uji coba pemakaian, revisi produk, dan produksi massal. ${ }^{12}$

Data yang digunakan dalam penelitian ini adalah data kuantitatif (berupa hasil penilaian angket dan hasil tes ujicoba produk) dan kualitatif (berupa masukan dan kritikan yang akan dijadikan sebagai acuan dalam perbaikan terhadap produk yang dikembangkan). Adapun untuk mengetahui tingkat kelayakan dari produk yang dihasilkan sebagai berikut: ${ }^{13}$

Tabel 1. Kualifikasi Tingkat Kelayakan Berdasarkan Presentase

\begin{tabular}{lll}
\hline Presentase $(\%)$ & Tingkat Kevalidan & Keterangan \\
\hline $\mathbf{8 4}<$ skor $\leq \mathbf{1 0 0}$ & Sangat valid & Tidak revisi \\
$\mathbf{6 8}<$ skor $\leq \mathbf{8 4}$ & Valid & Tidak revisi \\
$\mathbf{5 2}<$ skor $\leq \mathbf{6 8}$ & Cukup valid & Sebagian revisi \\
$\mathbf{3 6}<$ skor $\leq \mathbf{5 2}$ & Kurang valid & Revisi \\
$\mathbf{2 0}<$ skor $\leq \mathbf{3 6}$ & Sangat kurang & Revisi \\
& valid & \\
\hline
\end{tabular}

Kedua melalui eksperimen dengan melakukan tes untuk menguatkan, mengetahui dan menguji efektivitas produk media pembelajaran mufrodat yang telah dikembangkan. Eksperimen ini dilakukan untuk membandingkan hasil Pre test dan Post test sehingga efektivitas media pembelajaran yang baru dapat diukur melalui hasil tersebut. ${ }^{14}$ Adapun untuk menganalisis data tingkat perbandingannya maka Peneliti menggunakan rumus $t$ tes sebagai berikut: ${ }^{15}$

10 Sugiyono, Metode Penelitian Pendidikan Kuantitatif, Kualitatif Dan RnD (Bandung: CV. Alfabeta, 2011), hlm.297.

${ }^{11}$ Borg W.R. and Gall M.D., Educational Research: An Introduction, 4th Edition (London: Longman Inc., 1983).

12 Sugiyono, Metode Penelitian Pendidikan Pendekatan Kuantitatif, Kualitatif Dan RnD (Bandung: Alfabeta, 2012), hlm.407.

${ }^{13}$ Arikunto, Dasar-Dasar Evaluasi Pendidikan (Jakarta: Bumi Aksara, 2003), hlm.313.

14 Sugiyono, Metode Penelitian Pendidikan Kuantitatif, Kualitatif Dan RnD.

${ }^{15}$ Suharsimi Arikunto, Manajemen Penelitian (Jakarta: Rineka Cipta, 2005), hlm.509. 


$$
t=\frac{M d}{\sqrt{\frac{\sum d^{2}-\frac{\left(\sum d\right)^{2}}{n}}{n(n-1)}}}
$$

Keterangan:
$\mathrm{Md}$
= rata-rata dari gain antara tes akhir dan tes awal
d
= gain (selisih) skor tes akhir terhadap skor tes awal setiap subjek
$=$ jumlah subjek

\section{HASIL DAN PEMBAHASAN}

Pengembangan permainan kartu Kamal menggunakan model Borg and Gall yang telah dimodifikasi oleh Sugiyono dengan pembahasan sebagai berikut:

\section{Pengembangan Media Kartu Permainan Kamal}

Tahap pertama dalam pengembangan media ini adalah identifikasi masalah. analisis identifikasi masalah penulis lakukan dengan cara observasi kelas dan melakukan wawancara dengan mahasiswa semester I. Hasil dari kegiatan ini adalah adanya data kurangnya perbendaharaan mufrodat mahasiswa, pembelajaran bahasa Arab mengacu pada buku cetak dan belum adanya media pendukung untuk menunjang pembelajaran khususnya pada mufrodat. Berdasarkan hasil analisis, penulis menyimpulkan perlu adanya media pembelajaran khususnya untuk menambah perbendaharaan mufrodat yang dapat menambah minat dan motivasi mahasiswa dalam belajar Bahasa Arab dengan cara yang menyenangkan.

Tahapan selanjutnya adalah desain produk yang terdiri dari tahap perencanaan dan pengembangan. Pada tahapan perencanaan penulis mengumpulkan bahan berupa mufrodat bahasa Arab dan gambar ilustrasi terkait mufrodat, menentukan ukuran dan layout kartu.

pada tahap pengembangan, penulis mendesain kartu permainan dengan menggunakan aplikasi Corel Draw dengan memasukkan mufrodat dan gambar ilustrasi pada setiap kartu. Setelah itu kartu di cetak dengan menggunakan kertas ivory 280. Penulis merancang dua buah paket kartu permainan dalam tahapan ini. Berikut merupakan tampilan akhir kartu permainan Kamal.

Gambar 1 Mufrodat kartu kamal Seri 1
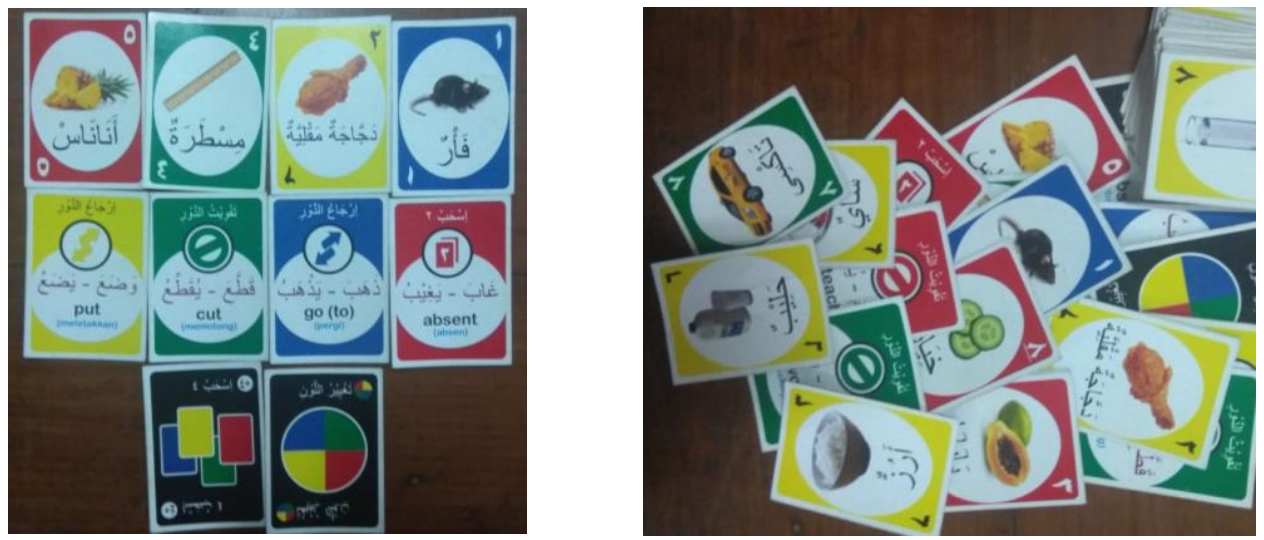
Gambar.2 Mufrodat kartu kamal Seri 2
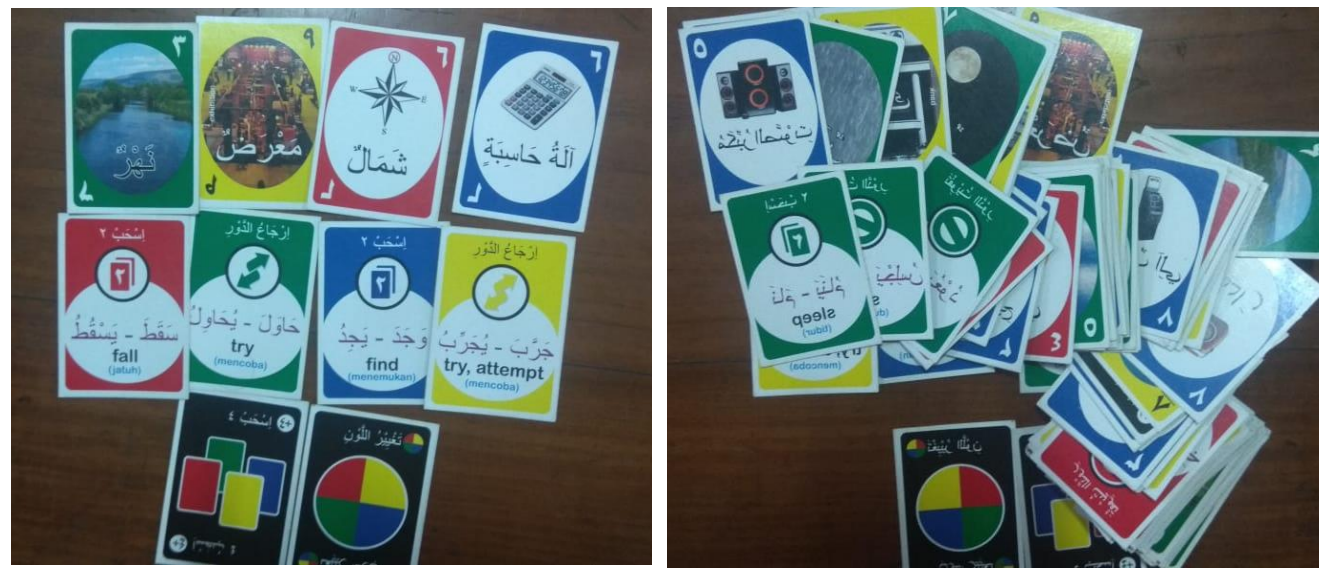

tahapan selanjutnya adalah validasi dan revisi desain yang dilakukan dari ahli media, ahli materi dan ahli pembelajaran. Pada tahap ini jika ada masukan dan perbaikan dari ahli maka produk akan direvisi.

Berikut adalah hasil validasi dari ahli media, materi dan pembelajaran.

Tabel 2. Data hasil validasi desain media

\begin{tabular}{|c|c|c|c|}
\hline No & Kriteria & Persentase & $\begin{array}{l}\text { Tingkat } \\
\text { Kevalidan }\end{array}$ \\
\hline 1. & Desain kartu sesuai dengan materi & $100 \%$ & Sangat Valid \\
\hline 2. & $\begin{array}{l}\text { Jenis Huruf yang digunakan sesuai } \\
\text { dengan pengguna }\end{array}$ & $100 \%$ & Sangat Valid \\
\hline 3. & $\begin{array}{l}\text { Ukuran huruf yang digunakan sesuai } \\
\text { dengan pengguna }\end{array}$ & $100 \%$ & Sangat Valid \\
\hline 4. & Gambar sesuai dengan mufrodat & $100 \%$ & Sangat Valid \\
\hline 5. & Gambar yang digunakan menarik siswa & $80 \%$ & Valid \\
\hline 6. & Tata letak gambar menarik & $100 \%$ & Sangat Valid \\
\hline 7. & Tata letak tulisan sesuai & $100 \%$ & Sangat Valid \\
\hline 8. & Ukuran gambar pada kartu tepat & $100 \%$ & Sangat Valid \\
\hline 9. & Warna pada kartu menarik & $100 \%$ & Sangat Valid \\
\hline \multirow[t]{2}{*}{10.} & Layout pada kartu menarik & $80 \%$ & Valid \\
\hline & Rata-rata & $96 \%$ & Sangat Valid \\
\hline
\end{tabular}

Berdasarkan data di atas, maka penilaian dari validator desain media secara keseluruhan mencapai rata-rata 96\%. Jika disesuaikan dengan tabel kriteria kelayakan (tabel 1) termasuk dalam kriteria sangat valid. Sehingga desain media pembelajaran layak dan sesuai untuk diimplementasikan pada pembelajaran bahasa Arab.

Tabel 3. Data hasil validasi isi/materi

\begin{tabular}{lllll}
\hline No & Kriteria & Persentase & $\begin{array}{l}\text { Tingkat } \\
\text { Kevalidan }\end{array}$ \\
\hline 1. & $\begin{array}{l}\text { Kesesuaian topik pada } \\
\text { media pembelajaran }\end{array}$ & pengembangan $100 \%$ & Sangat Valid \\
\hline
\end{tabular}




\begin{tabular}{llll}
\hline 2. & Keruntutan penyajian pembelajaran & $80 \%$ & Valid \\
3. & Kesesuain mufrodat dengan gambar & $100 \%$ & Sangat Valid \\
4. & Kejelasan mufrodat yang ada & $100 \%$ & Sangat Valid \\
5. & Ketepatan mufrodat dengan gambar & $100 \%$ & Sangat Valid \\
6. & $\begin{array}{l}\text { Kesesuain antara ukuran kartu dengan } \\
\text { ukuran gambar }\end{array}$ & $80 \%$ & Valid \\
7. & $\begin{array}{l}\text { Ketepatan penggunaan ilustrasi } \\
\text { Rata-rata }\end{array}$ & $80 \%$ & Valid \\
\hline
\end{tabular}

Berdasarkan data di atas, maka penilaian dari validator isi/materi secara keseluruhan mencapai rata-rata 92\% termasuk dalam kriteria sangat valid. Sehingga mufrodat yang dipilih telah layak dan sesuai untuk diimplementasikan pada pembelajaran bahasa Arab.

Tabel 4. Data hasil validasi ahli pembelajaran

\begin{tabular}{|c|c|c|c|}
\hline No & Kriteria & Persentase & Tingkat Kevalidan \\
\hline 1. & $\begin{array}{l}\text { Tingkat relevensi media pembelajaran dengan } \\
\text { kurikulum }\end{array}$ & $100 \%$ & Sangat Valid \\
\hline 2. & $\begin{array}{l}\text { Memudahkan guru dalam mengajar mata } \\
\text { kuliah bahasa Arab pada materi mufrodat }\end{array}$ & $100 \%$ & Sangat Valid \\
\hline 3. & Membantu guru dalam menyampaikan materi & $100 \%$ & Sangat Valid \\
\hline 4. & $\begin{array}{l}\text { Evaluasi dalam media pembelajaran dapat } \\
\text { meningkatkan pemahaman siswa terhadap } \\
\text { kemampuan penguasaan mufrodat }\end{array}$ & $100 \%$ & Sangat Valid \\
\hline 5. & $\begin{array}{l}\text { Kesesuaian ukuran dan jenis huruf yang } \\
\text { digunakan dalam media pembelajaran }\end{array}$ & $80 \%$ & Valid \\
\hline 6. & Kesesuaian gambar / ilustrasi dengan materi & $100 \%$ & Sangat Valid \\
\hline 7. & $\begin{array}{l}\text { Kemenarikan gambar yang digunakan dalam } \\
\text { media pembelajaran }\end{array}$ & $60 \%$ & Cukup Valid \\
\hline 8. & $\begin{array}{l}\text { Siswa termotivasi dalam mengikuti } \\
\text { pembelajaran bahasa Arab }\end{array}$ & $100 \%$ & Sangat Valid \\
\hline 9. & Peran media dalam pembelajaran bahasa Arab & $100 \%$ & Sangat Valid \\
\hline & Rata-rata & $93 \%$ & Sangat Valid \\
\hline
\end{tabular}

Berdasarkan data di atas, maka penilaian dari validator pembelajaran secara keseluruhan mencapai rata-rata 93\% termasuk dalam kriteria sangat valid. Sehingga penggunaan media kartu kamal untuk meningkatkan penguasaan mufrodat sangat layak untuk diterapkan dalam proses pembelajaran bahasa Arab.

Hal ini menunjukkan bahwa secara keseluruhan media pembelajaran berupa kartu kamal sangat valid, layak dan dapat diterima untuk diimplementasikan dalam pembelajaran mufrodat. Akan tetapi ada sedikit perbaikan ringan pada beberapa sisi berdasarkan saran ketiga Ahli seperti kejelasan gambar ilustrasi, perbaikan harokat pada tulisan serta petunjuk teknis penggunaan media sehingga dapat memudahkan penguasaan mufrodat siswa ketika pembelajaran didalam kelas. 


\section{Aspek Bahasa dan Keterampilan Berbahasa yang dikembangkan dengan media Pembelajaran Kartu Uno}

Media kartu kamal ini dapat digunakan dalam mengembangkan kemampuan khususnya penguasaan mufrodat. Aspek kemahiran yang bisa dikembangkan dengan kartu ini adalah kemahiran menyimak, berbicara dan membaca. Kartu ini didesain untuk pembelajaran bahasa Arab secara umum, tidak terkait secara spesifik dengan kurikulum, buku atau referensi tertentu, pemilihan tema mufrodat diambil dari mufrodat yang paling dekat dan sering dijumpai di tengah-tengah pengguna.

Kartu yang didesain oleh penulis meliputi gambar, kosakata tematik dalam kartu dan cara permainan. Adapun deskripsi dari produk media yang dikembangkan adalah sebagai berikut:

a. Kartu kamal terdiri dari dua jenis yaitu kartu biasa dan aksi. Semua kartu ini berisikan mufrodat meliputi kata benda (isim) dan kata kerja (fiil).

b. Kartu biasa berisikan mufrodat berupa kata benda (isim) beserta gambarnya yang memiliki angka dari 0 hingga 9 dengan 4 warna yang berbeda yaitu merah, biru, hijau, dan kuning. Jumlah kartu biasa ini adalah 76 kartu sehingga total mufrodat isim dalam kartu tersebut sebanyak 76 kartu.

c. Kartu aksi berisikan mufrodat berupa kata kerja (fiil) beserta artinya dalam bahasa Inggris dan Indonesia, yang memiliki fungsi khusus dalam permainan. Jumlah total dari kartu aksi ini adalah 32 kartu. Terdapat lima jenis kartu aksi dalam permainan kartu kamal yaitu, 1) Ambil dua / Draw

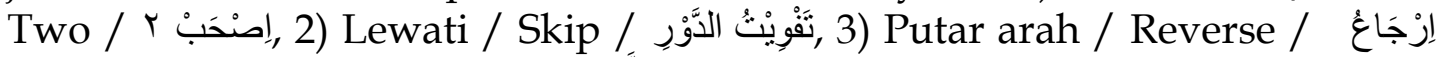
(4) Ubah warna / Wild/ الدَّْر / 5) Ambil empat dan Ubah Warna / Wild four / إصنَْبْ ؛

d. Jumlah Total Kosakata dalam setiap seri kartu kamal adalah 100 kosakata (76 isim dan 24 fiil). Dalam kartu ini terdapat 8 kartu lain yang tidak berisi kosakata yang dinamakan dengan kartu khusus (WILD). Kartu ini memiliki fungsi tertentu dalam permainan kartu kamal. Total keseluruhan kartu adalah 108 kartu.

e. Warna cover setiap kartu berbeda. Pada seri 1 berwarna hitam dan seri 2 berwarna coklat.

f. Pada setiap kartu dilengkapi dengan cara atau petunjuk permainan.

Berikut adalah spesifikasi kartu Kamal Seri I dan Seri II.

Tabel 5. Spesifikasi produk media kartu pembelajaran

\begin{tabular}{ll}
\hline Bentuk & Bahan cetak (material printed) \\
\hline Nama & Kamal \\
\hline Sasaran & Pembelajar bahasa Arab usia 12 tahun keatas \\
\hline Nama Pengarang & M. Syamsul Maarif \\
Jumlah Kartu & 108 kartu (100 kartu biasa dan 8 kartu aksi) \\
Cetakan & Pertama \\
Ukuran kartu & $6,5 \times 9 \mathrm{~cm}$ \\
\hline Jumlah mufrodat isim & 76 \\
\hline
\end{tabular}




\begin{tabular}{|c|c|}
\hline Jumlah mufrodat fiil & 24 \\
\hline Tema mufrodat kartu I & $\begin{array}{l}\text { 1) Makanan, 2) Minuman, 3) Tranportasi, 4) alat } \\
\text { tulis (perlengkapan sekolah), 5) hewan, 6) kata } \\
\text { kerja populer. }\end{array}$ \\
\hline Tema mufrodat kartu II & $\begin{array}{l}\text { 1) Warna, 2) Arah, 3) Alam, 4) Elektronik, 5) } \\
\text { Bangunan dan Tempat, 6) Kata kerja populer. }\end{array}$ \\
\hline Jumlah pemain & $2-10$ orang \\
\hline Cara Permainan & $\begin{array}{l}\text { Menyamakan angka atau warna kartu dengan } \\
\text { menyebutkan kosakata yang ada didalamnya. } \\
\text { Pemenang ditentukan oleh pemain dengan kartu } \\
\text { yang telah habis atau perolehan kartu yang paling } \\
\text { sedikit. } \\
\text { Ada dua tipe kartu, yaitu kartu biasa yang berisi } \\
\text { mufrodat dan kartu aksi yang memiliki fungsi } \\
\text { tertentu yang membuat permainan lebih } \\
\text { menyenangkan. } \\
\text { Bahasa pengantar yang digunakan dalam bermain } \\
\text { dilakukan secara bertahap, dari campuran bahasa } \\
\text { Arab dan Indonesia hingga menggunakan bahasa } \\
\text { Arab secara penuh. }\end{array}$ \\
\hline
\end{tabular}

\section{Penerapan Permainan Kartu Kamal dalam Pembelajaran}

Tahapan selanjutnya adalah penerapan produk media kartu kamal dalam kelas. Kartu permainan ini bisa digunakan kapanpun, baik di dalam atau di luar pembelajaran, karena kartu ini bersifat umum dan tidak terkait secara khusus dengan kurikulum atau buku tertentu. Kartu ini bisa dijadikan sebagai tambahan dan penunjang kemampuan siswa dalam bahasa Arab.

Berikut adalah langkah-langkah penerapannya:

a. mahasiswa dibagi dalam beberapa kelompok, kelompok bisa terdiri dari 5-10 pemain.

b. para pemain duduk secara melingkar dan rapat.

c. guru/dosen menjelaskan cara permainan kartu kamal dan aturan-aturan permainannya.

d. salah seorang pemain diminta untuk mengocok kartu terlebih dahulu lalu membagikan kepada setiap pemain 7 buah kartu.

e. satu kartu diambil untuk dikadikan kartu tarikan/draw card untuk menjadi kartu pembuka. Kartu tarikan adalah jenis kartu biasa.

f. selanjutnya para pemain secara bergiliran (searah jarum jam) mengeluarkan kartu yang sesuai dengan kartu tarikam dengan cara menyamakan angka atau warna kartu.

g. Selanjutnya pemain secara bergiliran (searah jarum jam) mengeluarkan kartu sesuai dengan kartu pembuka dengan cara "menyamakan warna 
atau angka" yang tertera pada kartu yang dimainkan. Pemain yang tidak mempunyai kartu dengan warna yang sama atau angka yang sama dengan kartu yang dimainkan harus mengambil kartu dari kartu tarikan/draw card sampai dia mendapatkan kartu dengan warna atau angka yang sama atau kartu

h. Setiap pemain harus menyebutkan kosakata yang tertera pada setiap kartu yang dimainkan, baik kartu biasa maupun kartu aksi. (kartu biasa : menyebutkan kosakata (isim) lalu membuang kartu yang dimaksud, misalnya: kitaabun/kitaab. Kartu aksi : menyebutkan kosakata (fiil) kemudian menyebutkan perintah dari kartu aksi tersebut, misalnya : kataba-yaktubu - irjaaud-daur, ishab isnain, ishab arba'ah, dsb).

i. Pemain yang lupa tidak menyebutkan kosakata dalam kartu ketika membuang kartu dan ada pemain lain yang mengingatkannya maka pemain tersebut mendapatkan hukuman dengan mengambil satu kartu dari kartu tarikan/draw card.

j. Ketika ada pemain yang kartunya hanya tersisa satu kartu, maka dia harus berteriak "KAMAL" agar pemain lainnya mendengar dan waspada. Ketika pemain tersebut tidak menyebutkan kata "KAMAL", dan ada pemain lain yang tahu dan mengucapkan "KAMAL" kepadanya, maka pemain yang punya sisa satu kartu tersebut harus mengambil dua kartu dari kartu tarikan sebagai hukuman.

k. Para pemain diwajibkan untuk menggunakan bahasa Arab dalam permainan secara bertahap. Berikut adalah beberapa jenis kosakata dalam permainan yang harus dilafalkan dengan bahasa Arab.

Pertama : Kosakata+kata perintah dalam kartu

Kedua : Kosakata+kata perintah+warna kartu (pemain tidak boleh lagi menyebutkan warna merah, biru, kuning, hijau atau hitam, melainkan dengan menggantinya dengan أسود، أزرق، أسفر، أزرق، أحمر (kangan)

Ketiga : Kosakata+kata perintah+warna+angka kartu. Pemain tidak boleh lagi mengucapkan angka dengan bahasa Indonesia misalnya satu, dua, tiga, dst, melainkan harus menggantinya dengan واحد، اثنان، ثلاثة

Keempat : semua obrolan dalam permainan diucapkan dengan bahasa Arab.

\section{Kartu Aksi}

a. Kartu Draw Two (+2) (إصنحَبْ إِنْتَنْن) : kartu ini membuat pemain berikutnya harus mengambil dua kartu dari kartu tarikan. Setelah mengambil dua kartu tarikan kemudian pemain tersebut diperbolehkan mengeluarkan kartu sesuai dengan kartu yang dimainkan, jika pemain tersebut tidak mempunyai kartu yang dimainkan maka permainan langsung dilanjutkan dengan pemain berikutnya. Kartu ini tidak bisa dilawan dengan kartu draw two yang lain. 
b. Kartu Reverse (إرْجَاعُ الدَّوْرِ) : kartu ini hanya mengubah arah atau alur putaran permainan, permainan yang awalnya dimainkan searah jarum jam (kiri-kanan) menjadi berlawanan arah dengan jarum jam (kanankiri). Kartu ini bisa dilawan dengan kartu skip lain dengan warna yang berbeda.

c. Kartu Skip (تَفْوِيَتُ الدَّوْرِ) : kartu ini membuat pemain berikutnya dilewati atau di skip sehingga dia tidak bisa mengeluarkan kartu. Kartu ini tidak bisa dilawan dengan kartu manapun.

d. Kartu Wild (تَغْيْرُ اللَّونِْ : kartu ini bisa digunakan untuk kartu warna apa saja. Setelah itu pemain yang mengeluarkan kartu ini, berhak menentukan warna apa yang harus dikeluarkan oleh pemain berikutnya. (misalnya: kartu yang dimainkan adalah kartu warna kuning dengan angka 3, kemudian pemain berikutnya tidak mempunyai kartu berwarna kuning atau kartu warna lain dengan angka 3, maka dia boleh mengeluarkan kartu wild ini, dan menentukan warna sesuai dengan kehendaknya.

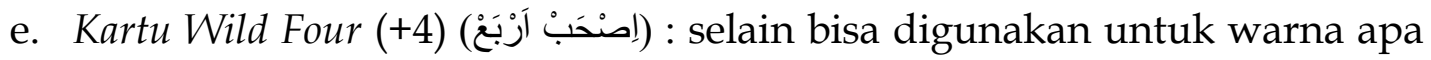
saja, kartu ini memaksa pemain berikutnya untuk mengambil 4 kartu dari kartu tarikan. Setelah itu pemain yang membuang kartu ini menentukan warna apa yang harus dikeluarkan oleh pemain tersebut. (Setelah mengambil empat kartu tarikan sebagai akibat dari kartu aksi wild four, pemain tersebut kemudian mengeluarkan kartu sesuai dengan permintaan warna yang diajukan oleh pemain yang mengeluarkan kartu wild four. Jika pemain tersebut tidak mempunyai kartu yang dimainkan maka permainan langsung dilanjutkan dengan pemain berikutnya.

Pemenang

a. Permainan berakhir ketika ada salah satu pemain yang kartunya sudah habis atau kartu tarikan/draw card sudah habis.

b. Ketika ada pemain yang berhasil menghabiskan kartu, maka pemain lain menghitung jumlah kartu sisa yang masih dibawa. Pemegang kartu dengan nilai terbanyak adalah yang kalah. (pemain bisa menulis skor akhir tiap pemain dalam setiap permainan dalam buku atau kertas)

c. Ketika kartu tarikan/draw card sudah habis sedangkan belum ada pemain yang bisa menghabiskan kartunya, maka permainan diakhiri dan pemenang ditentukan dengan cara menghitung jumlah total nilai kartu yang dibawa oleh setiap pemain.

d. Pemenang dari permainan ini adalah pemain dengan kartu yang paling cepat habis, atau pemain dengan jumlah total nilai paling sedikit diantara pemain lainnya. 
e. Permainan ini membutuhkan strategi untuk menang, setiap pemain berhak mengeluarkan kartu atau tetap menyimpan kartu yang dimilikinya dengan maksud memenangkan permainan.

f. Pemain diperbolehkan untuk berdiskusi dengan pemain lain untuk menggagalkan kemenangan dari pemain yang kartunya tinggal satu atau pemain yang sudah mengucapkan "KAMAL".

\section{Penilaian}

a. Kartu biasa : dinilai dari angka yang tertera di kartu.

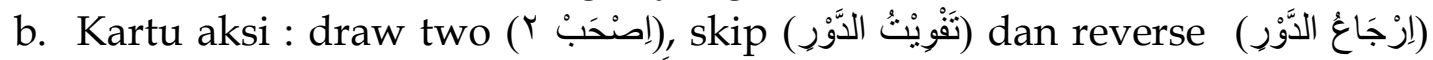

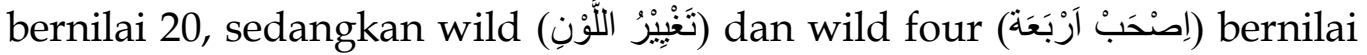
50.

c. Pemain yang kalah bisa dihukum dengan mengocok kartu dan menyebutkan minimal 10 mufrodat.

d. Pemain yang menang, selanjutnya mendapatkan giliran pertama untuk mengeluarkan kartu setelah kartu pembuka.

\section{Efektivitas produk}

Implementasi dan ujicoba produk media pembelajaran kartu kamal dalam meningkatkan mufrodat dilakukan setelah Peneliti melakukan revisi berdasarkan masukan dan saran dari beberapa Ahli. Ujicoba dilakukan untuk mengetahui dan memperoleh hasil efektivitas kartu kamal dalam meningkatkan penguasaan mufrodat. Untuk memperoleh hasil efektivitas kartu kamal maka dilakukan sebuah tes yang meliputi pre test dan post test. Pre test dilakukan oleh Peneliti sebelum menggunakan atau menerapkan media permainan kartu kamal dalam proses pembelajaran. Sedangkan post test dilakukan Peneliti sesudah menggunakan atau menerapkan media permainan kartu Kamal dalam proses pembelajaran. Adapun yang menjadi objek penelitian adalah Mahasiswa IAIN Kediri prodi bahasa Arab kelas LAM B sebanyak 25 orang dan LAM D sebanyak 16 orang. Akan tetapi jumlah Mahasiswa yang digunakan setiap kelasnya sekitar 14 orang yang kemudian akan dibagi menjadi 2 kelompok untuk memainkan kartu dengan tema yang berbeda sebanyak $2 x$ permainan.

Awalnya pembelajaran mufrodat dilakukan tanpa menggunakan media kartu kamal. Setelah itu, Peneliti melakukan Pre test untuk mengetahui hasil penguasaan mufrodat Mahasiswa. Selanjutnya, dalam proses pembelajaran Peneliti menggunakan media permainan kartu kamal untuk mempelajari mufrodat didalam kelas. Kemudian Peneliti melakukan post test untuk mengetahui hasil penguasaan mufrodat setelah menggunakan media kartu kamal. Kegiatan tersebut dilakukan secara berulang kali untuk memperoleh hasil efektivitas dari media kartu kamal. Berikut hasil pre test dan post test dari Mahasiswa semester pertama kelas “LAM B dan LAM D" sebagai berikut:

Tabel 6. Hasil Pre-test dan post-test Kartu Seri 1 dan 2 


\begin{tabular}{llllll}
\hline $\begin{array}{l}\text { N } \\
\text { o }\end{array}$ & Kartu & $\begin{array}{l}\text { Nilai } \\
\text { Pre test }\end{array}$ & $\begin{array}{l}\text { Nilai Post } \\
\text { test 1 }\end{array}$ & $\begin{array}{l}\text { Nilai } \\
\text { Post test } \\
\mathbf{2}\end{array}$ & $\begin{array}{l}\text { Rata-rata } \\
\text { Post test }\end{array}$ \\
\hline 1. & Kelas B Seri 1 & 70,85 & 85,14 & 98,28 & 91,71 \\
2. & Kelas B Seri 2 & 46,85 & 69,14 & 78,85 & 74 \\
3 & Kelas D Seri 1 & 40,57 & 55,42 & 68 & 61,71 \\
4. & Kelas D Seri 2 & 41,14 & 49,14 & 66,28 & 57,71 \\
\hline
\end{tabular}

Berdasarkan tabel diatas menunjukkan bahwa rata-rata nilai post test lebih bagus daripada nilai pre test. Kemudian akan dianalisis menggunakan uji t satu kelompok dengan taraf signifikan 0,05 , sebagai berikut:

1) Peneliti menjelaskan hasil normalitas sebaran data

Tabel 7. Hasil normalitas sebaran data

\begin{tabular}{llcc}
\hline $\mathbf{N}$ & Kelas & Seri $\mathbf{1}$ & Seri 2 \\
$\mathbf{0}$ & & \\
\hline 1. & Kelas B & 20,86 & 27,15 \\
2. & Kelas D & 21,14 & 16,57 \\
\hline & & \\
$\begin{array}{l}\text { 2) Membahas hasil Uji- t } \\
\text { Tabel 8. Hasil Uji-t }\end{array}$ & & \\
\hline $\mathbf{N}$ & Kelas & Seri 1 & Seri 2 \\
$\mathbf{0}$ & & \\
\hline 1. & Kelas B & 5,390 & 6,890 \\
2. & Kelas D & 9,353 & 9,054 \\
\hline
\end{tabular}

3) Membahas Kriteria pengujian

Jika $-t^{\text {tabel }}<t^{\text {hitung }}<t^{\text {tabel }}$ maka tidak berbeda secara signifikan. Sedangkan jika $t^{\text {hitung }}>t^{\text {tabel }}$ atau $t^{\text {hitung }}<-t^{\text {tabel }}$ maka terdapat perbedaan yang signifikan.

Tabel 9. Kriteria pengujian

\begin{tabular}{ll}
\hline Derajat kebesaran $(\mathrm{db})$ & $: 6$ \\
Taraf Signifikansi & $: 0,05$ \\
tabel & $: 2,466$ \\
\hline
\end{tabular}

4. membandingkan t tabel $^{\text {dengan }}$ thitung $^{\text {th }}$

Tabel 10. Perbandingan t-tabel dan t-hitung

\begin{tabular}{lllll}
\hline $\mathbf{N}$ & Kelas & $\begin{array}{l}\text { Seri 1 } \\
\text { Thitung }\end{array}$ & $\begin{array}{l}\text { Seri 2 } \\
\text { Thitung }\end{array}$ & Ttabel \\
\hline 1. & Kelas B & 5,390 & 6,890 & \multirow{2}{*}{2,466} \\
\hline 2. & Kelas D & 9,353 & 9,054 & \\
\hline
\end{tabular}




\section{Menyimpulkan data}

Berdasarkan perbandingan antara hasil $t^{\text {hitung }}$ dan $t^{\text {tabel }}$, maka dapat ditarik sebuah hasil bahwa terdapat perbedaan yang signifikan dalam penguasaan mufrodat antara sebelum dan sesudah menggunakan media permainan kartu kamal. Adapun dari hasil uji t diperoleh $t^{\text {hitung }}>t^{\text {tabel }}$. Hasil $t^{\text {hitung }}$ dengan tingkat sign 0,05 (5\%) pada kelas LAM “B” seri 1 dan 2 adalah 5,390 dan 6,890 maka $t^{\text {tabel }}$ nya adalah 2,466 dengan koefisisen $(\mathrm{dk}=6)$. Sedangkan untuk kelas LAM “D” hasil $t^{\text {hitung }}$ seri 1 dan 2 adalah 9,353 dan 9,054 maka $t^{\text {tabel }}$ nya juga sama yaitu 2,466 dengan koefisisen $(\mathrm{dk}=6)$. Hal ini menunjukkan bahwa pengembangan media permainan kartu kamal "efektif" untuk meningkatkan penguasaan mufrodat Mahasiswa semester pertama di IAIN KEDIRI dan dapat menambah pembendaharaan kosakata pada setiap individu sehingga memudahkan Mahasiswa dalam berkomunikasi pada saat proses pembelajaran bahasa Arab.

Untuk memperkuat hasil uji $t$ mengenai efektivitas pengembangan media permainan kartu kamal, Peneliti melakukan wawancara kepada beberapa mahasiswa untuk mengetahui pendapat mereka tentang penggunaan media permainan kartu kamal pembelajaran mufrodat. Hasil dari wawancara menunjukkan hasil respon positif dari mahasiswa dalam penggunaan kartu permainan kamal.

Beberapa tanggapan mahasiswa dalam penggunaan kartu kamal adalah a) media kartu kamal membantu mengingat kembali mufrodat lama, b) media kartu kamal menambah perbendaharaan mufrodat baru, c) media kartu kamal menambah motivasi dalam belajar bahasa Arab, d) media kartu kamal menyenangkan dan tidak membosankan dalam belajar mufrodat.

\section{PENUTUP}

Berdasarkan penelitian diatas dapat diambil kesimpulan sebagai berikut:

1. media permainan kartu kamal dikembangkan melalui prosedur penelitian pengembangan model Borg \& Gall. Media didesain dengan menggunakan aplikasi Corel Draw. Materi yang dikembangkan adalah aspek mufrodat dengan tema-tema tertentu dan keterampilan berbahasa. Setelah desain jadi dan dicetak, kemudia divalidasi oleh ahli media, ahli materi dan ahli pembelajaran. Tahap selanjutnya adalah penerapan media dalam pembelajaran.

2. Hasil efektifitas dari media permainan kartu kamal ini dilihat dari perbedaan nilai pre-test dan post-test mahasiswa. Adapun dari hasil uji t diperoleh $t^{\text {hitung }}>t^{\text {tabel }}$ untuk kelas LAM “B” pada kartu $1 t^{\text {hitung }}$ nya adalah 5,390 dan pada kartu $2 t^{\text {hitung }}$ nya adalah 6,890 dengan koefisisen $(\mathrm{dk}=6)$ maka $t^{\text {tabel }}$ nya adalah 2,466. Sedangkan untuk kelas LAM “D” pada kartu $1 t^{\text {hitung }}$ nya adalah 9,353 dan pada kartu $2 t^{\text {hitung }}$ nya adalah 9,054 dengan koefisisen $(\mathrm{dk}=6)$ maka $t^{\text {tabel }}$ nya juga sama yaitu 2,466 . Karena hasil $t^{\text {hitung }}$ lebih besar daripada $t^{\text {tabel }}$ sehingga dapat diambil 
kesimpulan bahwa pengembangan media permainan kartu kamal "efektif " untuk meningkatkan penguasaan mufrodat Mahasiswa semester 1 di Prodi PBA IAIN Kediri dan dapat menambah pembendaharaan mufrodat mahasiswa.

\section{Daftar Pustaka}

Aqib, Zainal, Profesionalisme Guru dalam Pembelajaran. Surabaya: Insan Cendikia, 2002.

Arikunto, Suharsimi. Manajemen Penelitian. Jakarta: Rineka Cipta, 2005.

Arikunto. Dasar-dasar Evaluasi pendidikan, Jakarta: Bumi Aksara, 2003.

Arsyad, Azhar. Bahasa Arab Dan Metode Pengajarannya. Yogyakarta: Pustaka Pelajar, 2004.

Borg W.R. and Gall M.D., Educational Research: An Introduction, $4^{\text {th }}$ edition. London: Longman Inc., 1983.

Djiwandono, M. Soenardi. Tes Bahasa dalam Pengajaran. Bandung: Penerbit ITB Bandung, 1996.

Indriana, Dina. Ragam Alat Bantu Media Pengajaran. Yogyakarta: Diva Press, 2011.

Kustandi, Cecep dan Bambang Sutjipto, Media Pembelajaran Manual dan Digital. Bogor: Ghalia Indonesia, 2013.

Machali, Rochayah. Pedoman Bagi Penerjemah. Jakarta: Grasindo, 2000.

Mustofa, Syaiful. Strategi Pembelajaran Bahasa Arab Inovatif. Malang:UIN Maliki Press, 2011.

Rasyidi, Abdul Wahab. Media Pembelajaran Bahasa Arab. Malang: UIN Maliki Press, 2009.

Sadiman, Arief S. dkk. Media Pendidikan Pengertian, Pengembangan dan Pemanfaatannya. Jakarta: PT. Rajagrafindo Persada, 2010.

Sanaky, Hujair AH. Media Pembelajaran Interktif- Inovatif. Yogyakarta: Kaukaba Dipantara, 2013.

Sugiyono. Metode Penelitian kuantitatif, kualitatif dan $R \mathcal{E} D$. Bandung: CV, Alfabeta, 2011.

Sugiyono. Metode Penelitian Pendekatan kuantitatif, kualitatif dan R E D. Bandung: CV, Alfabeta, 2012. 